\title{
I-NERI Annual Technical Progress Report 2007-004-K Development and Characterization of New High-Level Waste Forms for Achieving Waste Minimization from Pyroprocessing
}

Steven M. Frank

September 2010

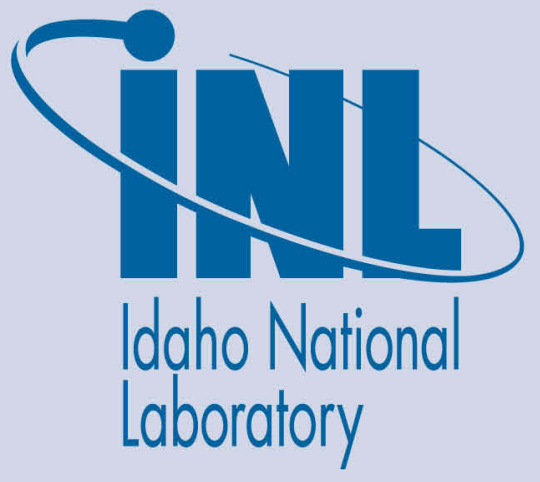

The INL is a U.S. Department of Energy National Laboratory operated by Battelle Energy Alliance 


\section{I-NERI Annual Technical Progress Report 2007-004-K Development and Characterization of New High-Level Waste Forms for Achieving Waste Minimization from Pyroprocessing}

Steven M. Frank

September 2010

Idaho National Laboratory

Idaho Falls, Idaho 83415

http://www.inl.gov

Prepared for the

U.S. Department of Energy

Office of Nuclear Energy

Under DOE Idaho Operations Office

Contract DE-AC07-05ID14517 


\title{
I-NERI ANNUAL TECHNICAL PROGRESS REPORT
}

Project Number and Title: 2007-004-K, Development and Characterization of New High-Level Waste Forms for Achieving Waste Minimization from Pyroprocessing

Lead U.S. Investigating Organization: INL

U.S. Principal Investigator: S. Frank

Lead Collaborating Investigating Organization: KAERI

Lead Collaborating Principal Investigator: Y.Z. Cho

Reporting Period: October 2009 - September 2010

\section{Narrative Subjects:}

Task A3 - Setup of Experimental Equipment and Methods for Hot-Testing (INL)

Task B2 - Waste form testing with TRU-loaded materials (INL)

Task C3 - Fabrication and characterization of optimized TRU-loaded waste forms (INL)

\begin{abstract}
The current method for the immobilization of fission products that accumulate in electrorefiner salt during the electrochemical processing of used metallic nuclear fuel is to encapsulate the electrorefiner salt in a glass-bonded sodalite ceramic waste form. This process was developed by Argonne National Laboratory in the USA and is currently performed at the Idaho National Laboratory for the treatment of Experimental Breeder Reactor-II (EBR-II) used fuel. This process utilizes a "once-through" option for the disposal of spent electrorefiner salt; where, after the treatment of the EBR-II fuel, the electrorefiner salt containing the active fission products will be disposed of in the ceramic waste form (CWF). The CWF produced will have low fission product loading of approximately 2 to 5 weight percent due to the limited fuel inventory currently being processed. However; the design and implementation of advanced electrochemical processing facilities to treat used fuel would process much greater quantities fuel. With an advanced processing facility, it would be necessary to selectively remove fission products from the electrorefiner salt for salt recycle and to concentrate the fission products to reduce the volume of high-level waste from the treatment facility.

The Korean Atomic Energy Research Institute and the Idaho National Laboratory have been collaborating on I-NERI research projects for a number of years to investigate both aspects of selective fission product separation from electrorefiner
\end{abstract}


salt, and to develop advanced waste forms for the immobilization of the collected fission products. The first joint KAERI/INL I-NERI project titled: 2006-002-K, Separation of Fission Products from Molten LiCl-KCl Salt Used for Electrorefining of Metal Fuels, was successfully completed in 2009 by concentrating and isolating fission products from actual electrorefiner salt used for the treated used EBR-II fuel. Two separation methods were tested and from these tests were produced concentrated salt products that acted as the feed material for development of advanced waste forms investigated in this proposal. Accomplishments from the first year activities associated with this I-NERI project included the down selection of candidate waste forms to immobilize fission products separated from electrorefiner salt, and the design of equipment to fabricate actual waste forms in the Hot Fuels Examination Facility (HFEF) at the INL. Reported in this document are accomplishments from the second year (FY10) work performed at the INL, and includes the testing of waste form fabrication equipment, repeating the fission product precipitation experiment, and initial waste form fabrication efforts.

\section{INTRODUCTION}

The purpose of this three-year, joint KAERI/INL I-NERI project is to develop novel high-level waste (HLW) forms and fabrication processes to dispose of active metal fission products that are removed from electrorefiner salts in the pyroprocessing-based fuel cycle. The current technology for disposing of active metal fission products in pyroprocessing involves non-selectively discarding fission product-loaded salt in a glass-bonded sodalite ceramic waste form. Selective removal of fission products from the molten salt would minimize the amount of HLW generation; and methods were developed to achieve selective separation of fission products during a previous I-NERI research project (I-NERI 2006-002-K). This INERI project expands from the previous project with the development of suitable waste forms to immobilize the separated fission products. The Korea Atomic Energy Research Institute (KAERI) has focused primarily on developing these waste forms using surrogate waste materials, and Idaho National Laboratory (INL) will demonstrate the "in-cell" fabrication and perform characterization and testing of the candidate waste forms in hot cell facilities available at INL.

The investigating fission product separation methods from electrorefiner (ER) salt resulted in a number of feasible options to concentrate and separate fission products from ER salt. These options are illustrated in Figure 1. Option A is a modification of the EBR-II spent fuel treatment process, where, instead of adding ER salt to zeolite and processing a low-loaded CWF; the zeolite is submerged in the salt and the cationic fission products ion exchange or occlude into the zeolite at high concentrations. The primary component of options B, C and D is oxygen sparging in the molten ER salt to chemically react with the rare-earth fission productions to produce oxychloride and oxide precipitates that can be physically separated from the ER salt. Other components of options $\mathrm{B}$ and $\mathrm{C}$ involve immobilizing the remaining group I and group II active fission products in a mineral form. The second component of option D involves zone-freezing of the ER electrolyte to concentrate both the remaining fission products dissolved in the salt along with the precipitated rare-earth fission products into a small volume of electrolyte. Several options then exist for waste form production from this concentrate. The preferred option developed by KAERI is to distill the salt off the precipitate and produce a silica- 
alumina-phosphate (SAP) waste form from the salt condensate and a zinc oxidetitania (ZIT) type waste form to immobilize the rare-earth precipitate.

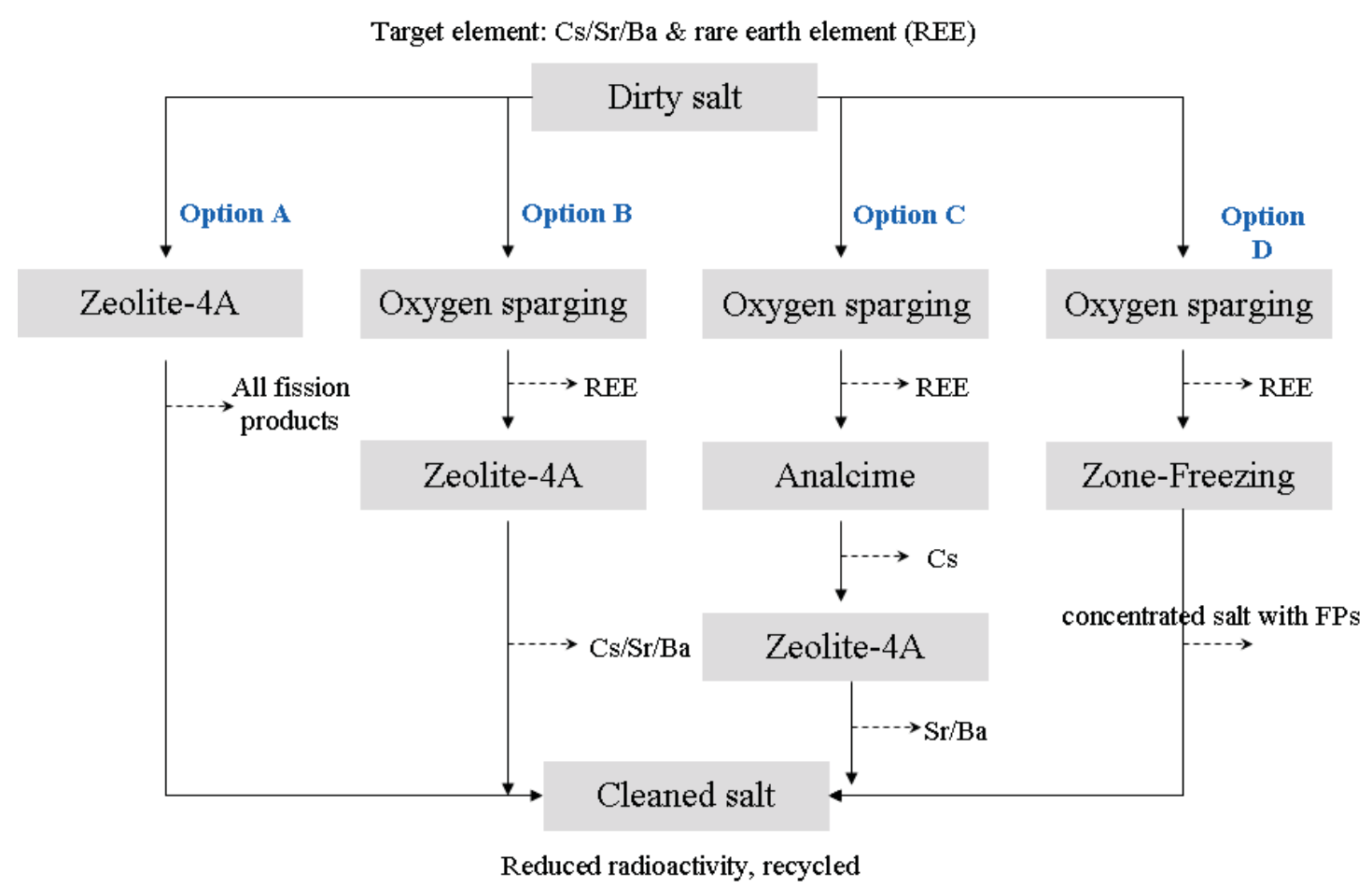

Fig. 1. Separation options for the removal of fission products from electrorefiner salt.

During the previous I-NERI separations project, a major task for the INL was to demonstrate two separation options, the salt/zeolite contacting indicated as option A, and oxygen sparging shown as the first component of options B, C, and D in Fig. 1 using actual ER salt in HFEF Demonstration of the two separation methods at the INL first involved testing the methods and equipment using surrogate salts in a nonradiological facility, then performing the actual demonstration using the Hot Fuels Dissolution Assembly (HFDA) in the HFEF facility hot cell. While the salt/zeolite contacting experiment yielded a usable material for CWF production, the oxygen sparging experiment did not yield sufficient rare-earth precipitate for subsequent waste form production. Analysis of the precipitation experiment indicated that nonoptimized conditions in the HFDA and appreciable quantities of actinide chlorides dissolved in the ER salt lead to a poor yield of rare-earth (lanthanide element) precipitate. A joint decision was made between KAERI and INL researchers to repeat the oxygen sparging experiment in the HFDA during the FY10 time period.

Reported here are the second year (FY10) I-NERI research activities performed at the INL. Specific activities research activities focus on the following:

- Repeat oxygen sparging experiment in the HFDA

- Fabrication and testing of waste form processing equipment

- Initiation of waste form production in HFEF.

\section{Repeat Oxygen Sparging Experiment in HFDA}

KAERI researchers have developed and effective method to chemically precipitate rare-earth (lanthanide element) fission products in ER salt by sparging oxygen gas 
through the molten ER salt. Molecular oxygen reacts with lanthanide chlorides to produce lanthanide oxide or oxychloride that then will precipitate to the bottom of the molten salt bath. This allows for the physical separation of the precipitated rareearth fission products from the salt and subsequent immobilization in a durable waste form. Because this salt/precipitate mixture is the bases for the development and characterization of advanced high-level waste forms I-NERI research project, it was vital to generate a usable quantity of fission product containing salt. To produce this material, the HFDA in the HFEF main cell was utilized. The HFDA consists of two main components, the base assembly, and the head assembly as shown in the cutaway diagram in Fig 2. The base assembly contains the heaters and the molten salt crucible. The head assembly is remotely removable from the base, and contains the access ports, the heat shield baffles, and equipment to hold and rotate experiments in the molten salt.

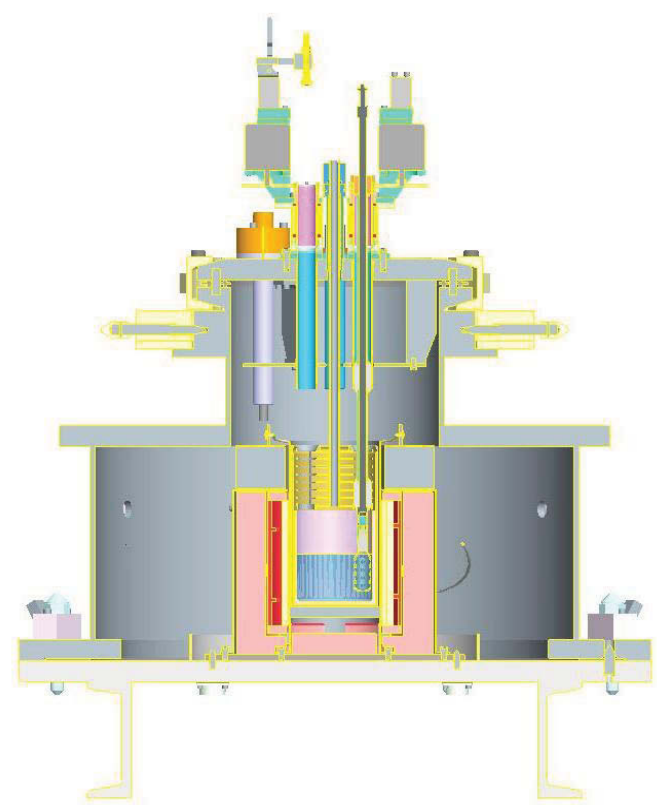

Fig. 2. Hot Fuels Dissolution Apparatus (HFDA) located in the HFEF main cell. The HFDA is an experimental-scale electrorefiner that was used for both the salt/zeolite and oxygen sparging experiments used to produce feed material for waste form development fabricated with Mark-IV electrorefiner salt.

The initial oxygen sparging experiment performed during FY09 period involved removal of the HFDF cover lid and placement of a precipitation collection pan into the molten salt bath. The cover lid was then placed back on the HFDA and the oxygen sparger (porous metal frit) inserted into the salt bath with an oxygen flow rate of $120 \mathrm{cc} / \mathrm{min}$. The temperature of the salt bath was maintained at $500^{\circ} \mathrm{C}$, and oxygen sparging was performed continuously for 24 hours with a total of $173 \mathrm{~L} \mathrm{O}_{2}$ bubbled into the HFDA salt. The sparger apparatus was then removed from the HFDA and the precipitate allowed to settle for another 24 hours into the collection pan while the HFDA remained at temperature. After precipitate settling, the head to the HFDA was removed and the collection pan slowly removed from the molten salt, allowed to cool, and the final salt sample was collected for analysis. Results from the first HFDA test are shown in Table 1 and compares the selective fission product removal by salt/zeolite contacting and by oxygen sparging precipitation. The results were obtained by measuring the elemental composition of the salt before and after the two selective separation methods. As shown in Table 1, salt/zeolite contacting was effective at reducing the concentration of lanthanides and actinide elements in the salt 
as indicated by a positive difference in concentration value. Following salt/zeolite contacting, oxygen sparging was performed to precipitate the remaining lanthanide elements. As can be seen in the table, the reduction in lanthanides from the salt was low, but the reduction in uranium concentration was high. Two conclusions were reached from these results regarding the performance of oxygen sparging in removing the lanthanide elements. The first was that the sparging experiment was not performed under optimum operating conditions and that the actinides were preferentially precipitated over the lanthanides - not an unexpected result when comparing the two element groups energy of formation of the oxide. For this reason, it was decided to repeat the oxygen sparging experiment in FY10 under more optimized conditions.

Table 1. Comparison of Selective fission Product Removal by Salt/Zeolite Contacting and Oxygen Precipitation.

\begin{tabular}{|l|l|l|}
\hline Difference in Elemental Concentration & Salt/Zeolite Contacting & Oxygen Precipitation \\
\hline Alkali and Alkaline Earth & $-14.7 \%$ & $2.8 \%$ \\
\hline Na & $0.6 \%$ & $2.6 \%$ \\
\hline Rb & $-0.4 \%$ & $0.7 \%$ \\
\hline Cs & $-1.5 \%$ & $1.5 \%$ \\
\hline Sr & $-1.5 \%$ & $1.7 \%$ \\
\hline Ba & & \\
\hline Lanthanides (and Y) & & $1.7 \%$ \\
\hline Y & $8.7 \%$ & $0.0 \%$ \\
\hline La & $8.3 \%$ & $-0.4 \%$ \\
\hline Ce & $7.0 \%$ & $-0.5 \%$ \\
\hline Pr & $9.4 \%$ & $1.0 \%$ \\
\hline Nd & $5.8 \%$ & $36.5 \%$ \\
\hline Sm & & $-3.6 \%$ \\
\hline Actinides & $13.1 \%$ & $-4.1 \%$ \\
\hline U & $7.2 \%$ & \\
\hline Np & & \\
\hline Pu & $35 \%$ & \\
\hline & & \\
\hline
\end{tabular}

The second oxygen sparging experiment performed in the HFDA in August of 2010 was very similar to the first, but with some important modifications. Equipment modifications included a redesign of the sparger unit, shown in Fig. 3, following the specifications suggested by researchers at KAERI, and increasing the height of the collection pan from $0.64 \mathrm{~cm}$ used during the first experiment to $1.27 \mathrm{~cm}$ used in the second experiment. The new precipitate collection pan is shown in Fig. 4 alongside the typical alumina crucibles used in the HFDA. Oxygen flow was increased during the second experiment to $427 \mathrm{~cm}^{3} / \mathrm{min}$ as compared to $118 \mathrm{~cm}^{3} / \mathrm{min}$ during the first experiment. The total quantity of $\mathrm{O}_{2}$ sparged into the molten salt was also increased during the second experiment to a total of $680 \mathrm{~L}$ vs. $170 \mathrm{~L}$ during the first experiment. 
Furthermore, investigation at KAERI indicates that the optimum molten salt bath temperature for oxygen precipitation of the lanthanides is $800^{\circ} \mathrm{C}$; however, the maximum temperature that the HFDA can be operated at is $650{ }^{\circ} \mathrm{C}$ and this is the temperature that the second oxygen sparging experiment was performed at, as opposed to $500^{\circ} \mathrm{C}$ during the first experiment.
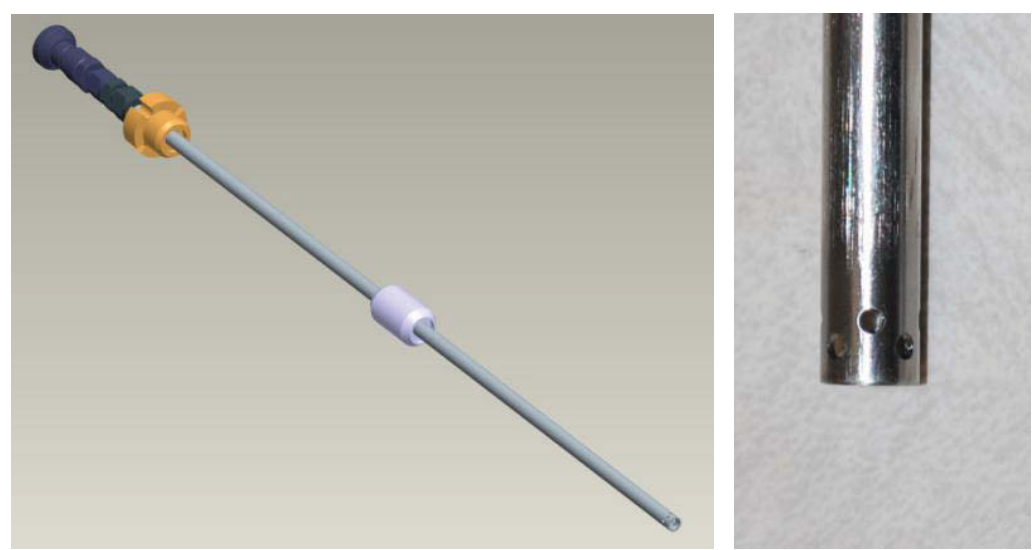

Fig. 3. Redesigned oxygen sparger used during second oxygen sparging experiment. The sparger is an open tube ( $6.2 \mathrm{~mm}$ ID) with $2 \mathrm{~mm}$ holes (right-hand image) drilled near the open tip of the sparger. This design resulted in larger $\mathrm{O}_{2}$ bubbles that spiraled through the molten salt resulting in a stirring action. This design also prevented clogging of the sparger which was common when using the porous metal frit design used during the first oxygen sparging experiment in the HFEA.

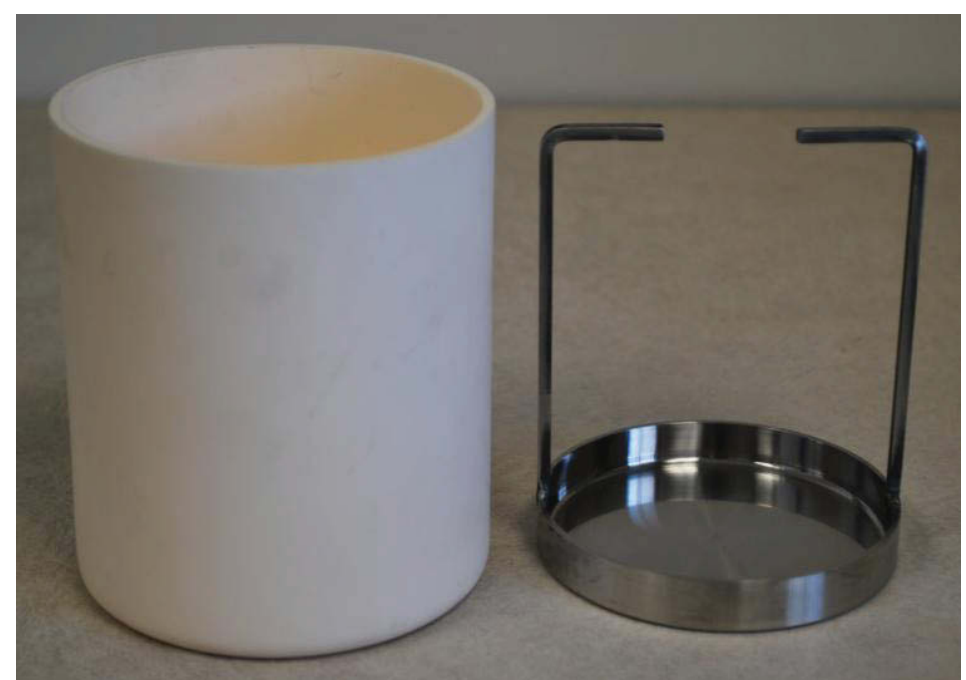

Fig. 4. Typical HFDA alumina crucible (11.4 cm high x $10.2 \mathrm{~cm} \mathrm{OD)}$ and stainless steel precipitate collection pan used during second oxygen sparging experiment.

The most significant difference between the first oxygen sparging experiment performed in FY09 and the second experiment conducted in August of 2010 was an actinide drawdown procedure prior to oxygen sparging. During actual electrorefining operations the actinide content of the molten electrolyte salt is keep relatively high. In an advanced electrorefining process, it is assumed that the actinide product would be harvested from the electrorefiner prior to any salt cleanup of fission products to minimize product loss. This two-step process was demonstrated during the August 2010 experiment. The initial salt composition was moderately high in actinide content as shown in Table 2. To this salt composition was added surrogate (non-radioactive), representative fission product chlorides, also 
shown in Table 2. This salt composition mimicked the expected ER salt composition resulting from the treatment of high burnup used fuel. To this molten salt stimulant was added $4.5 \mathrm{~g}$ of lithium metal to act as a reductant to the actinide elements present in the salt. As the actinide chlorides are reduced to the elemental state, they precipitated to the bottom of the crucible, where in this experiment; a collection pan had been place. After reducing the actinide material - the actinide drawdown portion of the experiment - the actinide collection pan was removed from the HFDA crucible and a second collection pan place in the molten salt bath, and oxygen sparging performed to precipitate the lanthanide elements. After a time period to allow the lanthanide oxides/oxychlorides to precipitate, the second collection pan was removed from the HFDA crucible. Both the first and second precipitate collection pans are shown in Fig. 5 after being removed from the molten salt bath. A number of salt samples were also collected before and after each of the chemical steps and have been submitted for elemental analysis. Results from these analyses are currently pending. The overall experimental plan is illustrated in Fig. 6. The salt/lanthanide precipitate product from the second collection pan was feed material used for subsequent waste form production. Visual inspection of the salt/oxide material (Fig. 8) indicates a stratified layer that may be separate phases of the lanthanide oxide/oxychloride precipitate and the residual salt material. Further investigation will be performed with electron microscopy of the interface material.

Table 2. Initial Salt Composition Used For Actinide Drawdown/Oxygen Sparging Experiment.

\begin{tabular}{|l|c|c|c|c|c|c|c|c|c|}
\hline $\begin{array}{l}\text { Initial Salt } \\
\text { Composition }\end{array}$ & $\begin{array}{c}\text { LiCl- } \\
\text { KCl }\end{array}$ & UCl3 & PuCl3 & NdCl3 & CsI & CeCl3 & LaCl3 & PrCl3 & SrCl2 \\
\hline Wt\% & 80.6 & 1.5 & 3.0 & 4.4 & 4.2 & 2.7 & 1.4 & 1.2 & 1.1 \\
\hline Grams & 831 & 15.5 & 30.9 & 45.4 & 43.3 & 27.8 & 14.4 & 12.4 & 11.3 \\
\hline
\end{tabular}

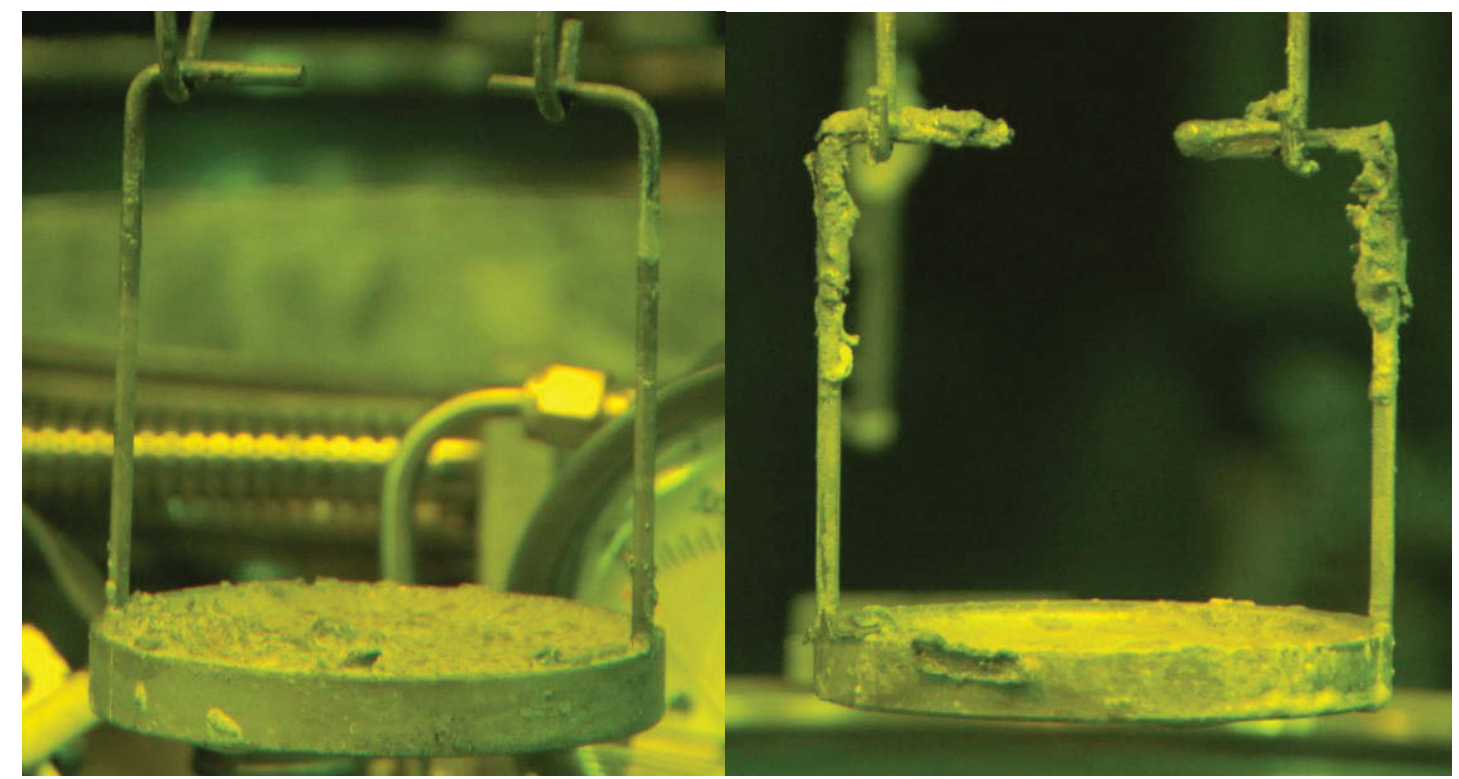

Fig. 5. Reduced actinide collection pan (left-hand picture) after removal from HFDA actinide drawdown experiment. Right-hand picture is the lanthanide oxide/oxychloride precipitate collection pan after oxygen spaging in the HFDA. 
Prior to waste form production, the salt/oxide precipitate mixture from collection pan 2 (Fig. 6) was broken out of the collection pan and ground to a course powder using an impact mortar (Fig. 7).

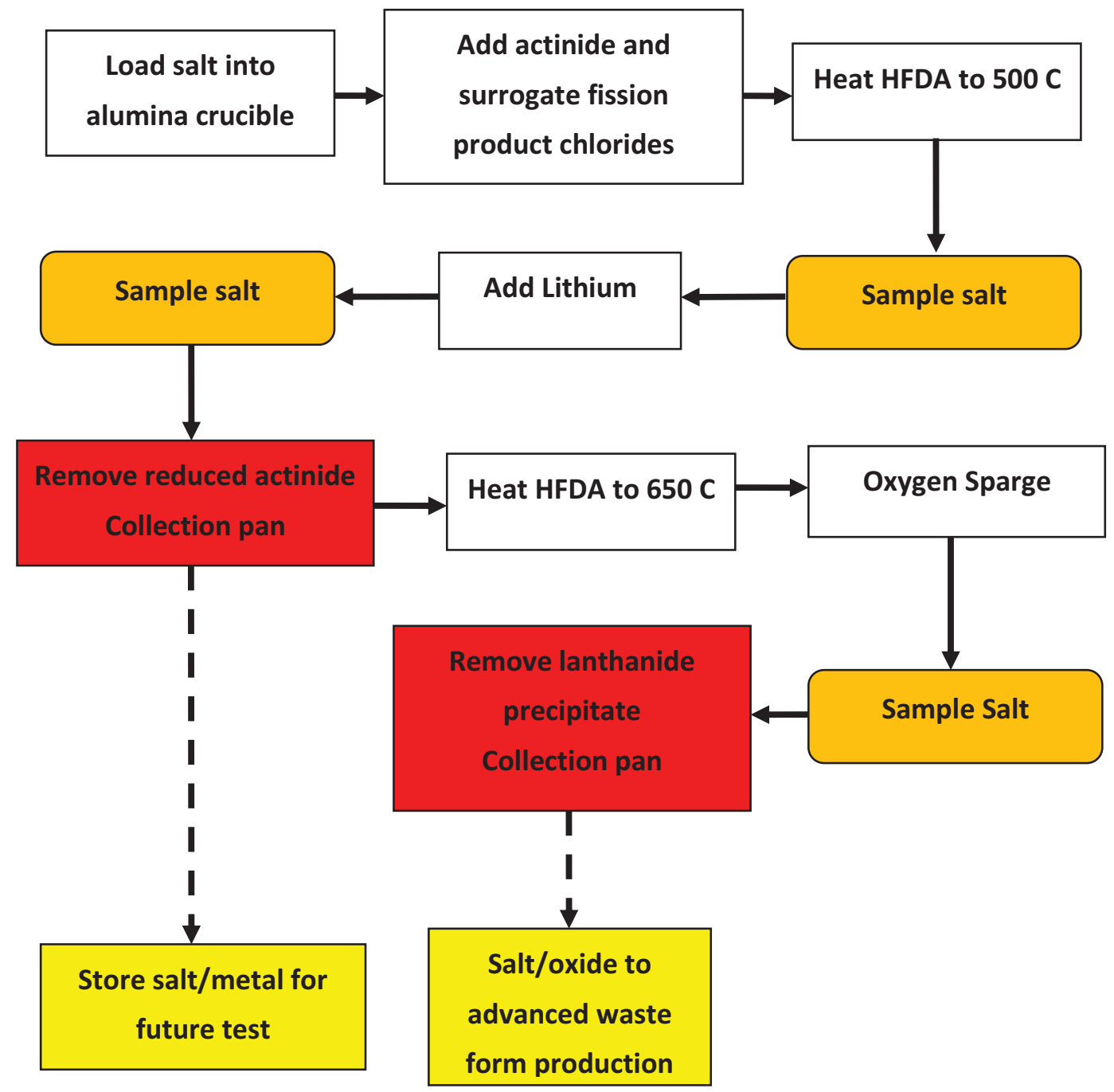

Fig. 6. Experimental plan for combined actinide drawdown/oxygen sparging experiment conducted in the HFDA in August 2010.

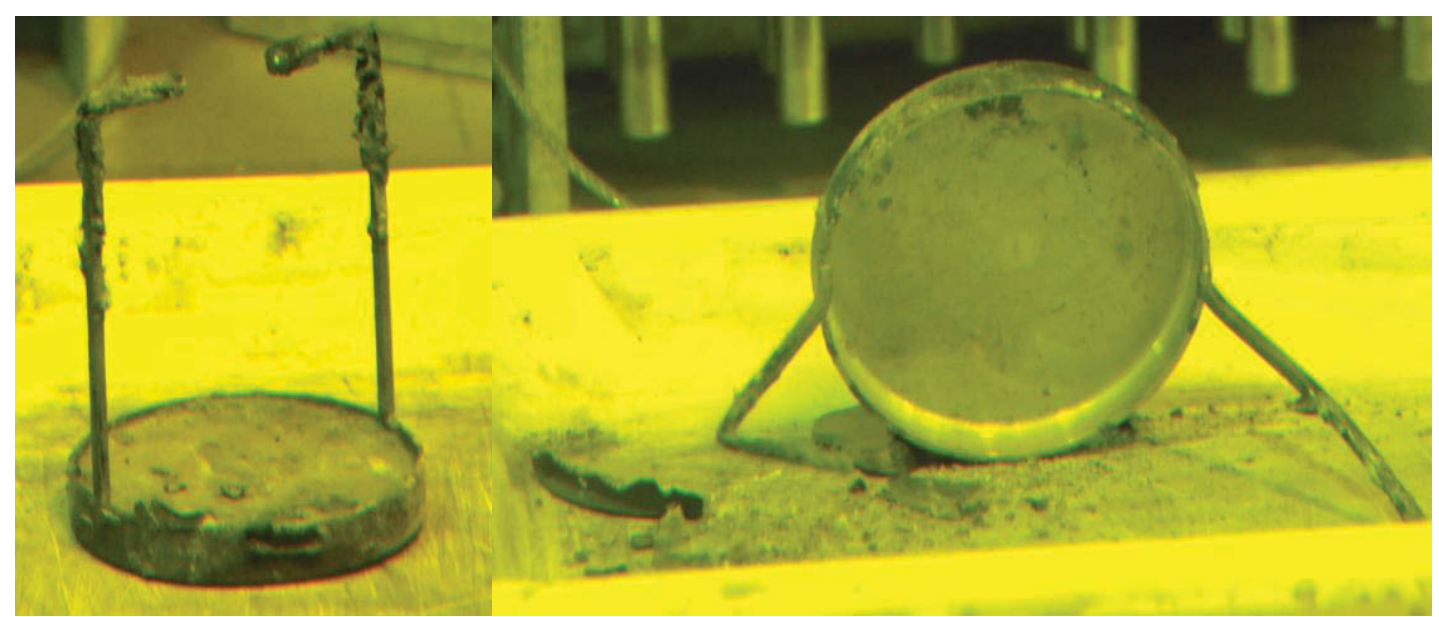

Fig. 6. Second collection pan containing salt/oxide precipitate from second sparging experiment. 


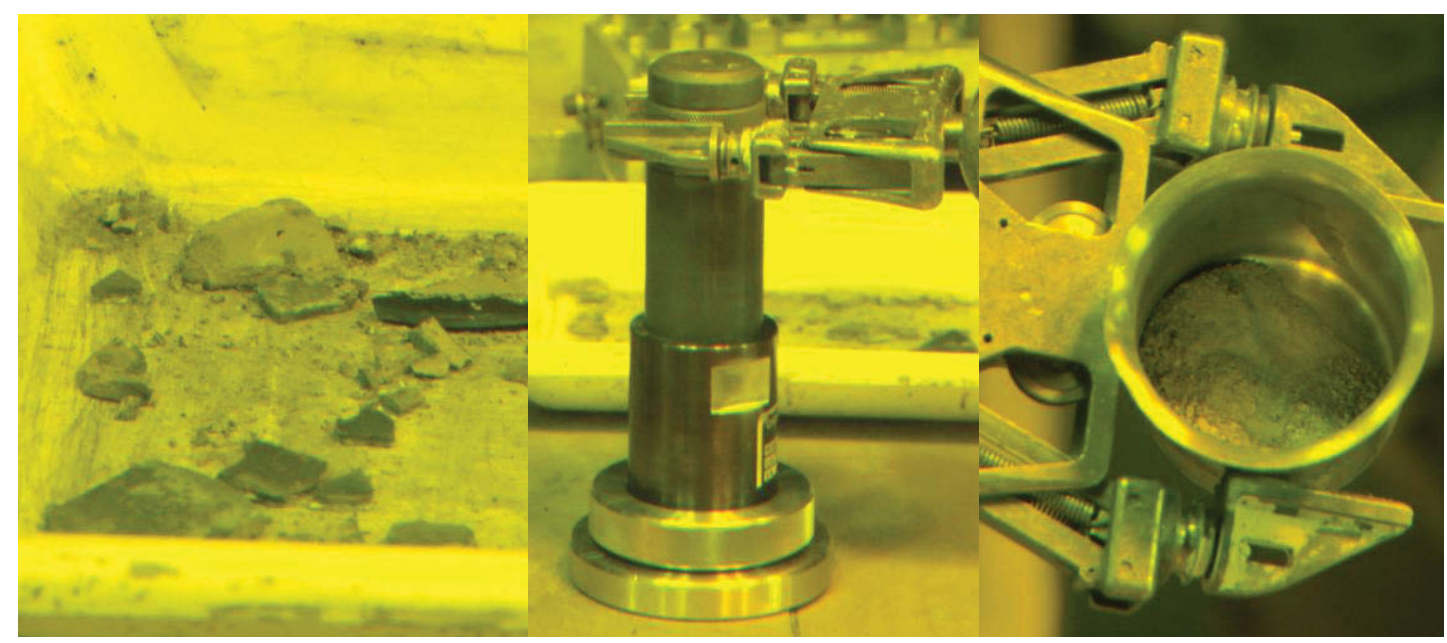

Fig. 7. T salt/oxide precipitate broken out of collection pan (left-hand image) was ground to a course powder using an impact mortor (center image), with the final ground salt shown in the right-hand image.

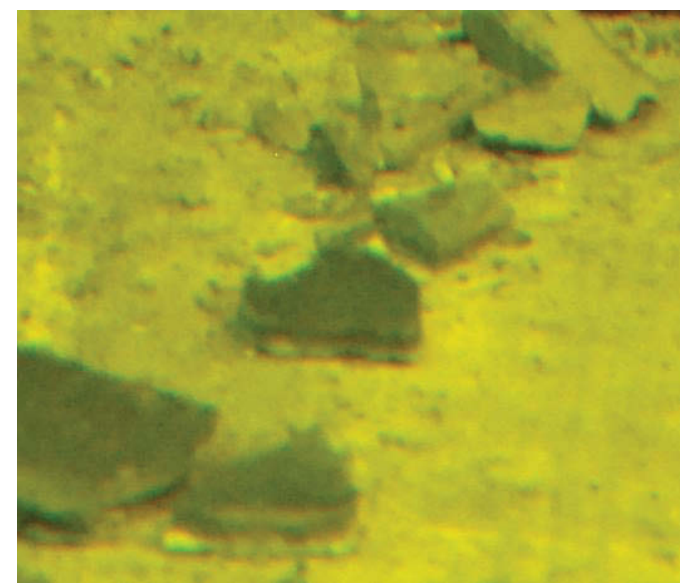

Fig. 8. Visual inspection of salt/oxide precipitate indicates the presence of a stratified layer that may indicate separation of the precipitate from the salt phase.

\section{HFEF Equipment Development and Testing for Advanced Waste Form Production}

KAERI researchers have proposed several novel waste forms for the immobilization of selectively separated fission products from ER salt. Two of the most promising waste forms, the SAP and ZIT materials, require dechlorination of the waste stream prior to processing. Two dechlorination methods will be demonstrated in HFEF; salt distillation and chemical reaction in an oxygenated atmosphere. Both dechlorination methods are performed at elevated temperatures and with controlled atmospheres. To performe these demonstration experiments, utilization of the DEOX (DEcladding by OXidation) furnace in the HFEF main cell was determined the best option. The DEOX furnace (Fig. 9) has four individual heat zones allowing treatment temperatures as high as $1200^{\circ} \mathrm{C}$. The furnace can also allow the introduction of controlled atmospheres such as oxygen feed or application of a high vacuum. Utilization of the DEOX furnace required the modification of the reaction/filter-bank assembly, used in the original DEOX experiments, with dechlorination assemblies. 

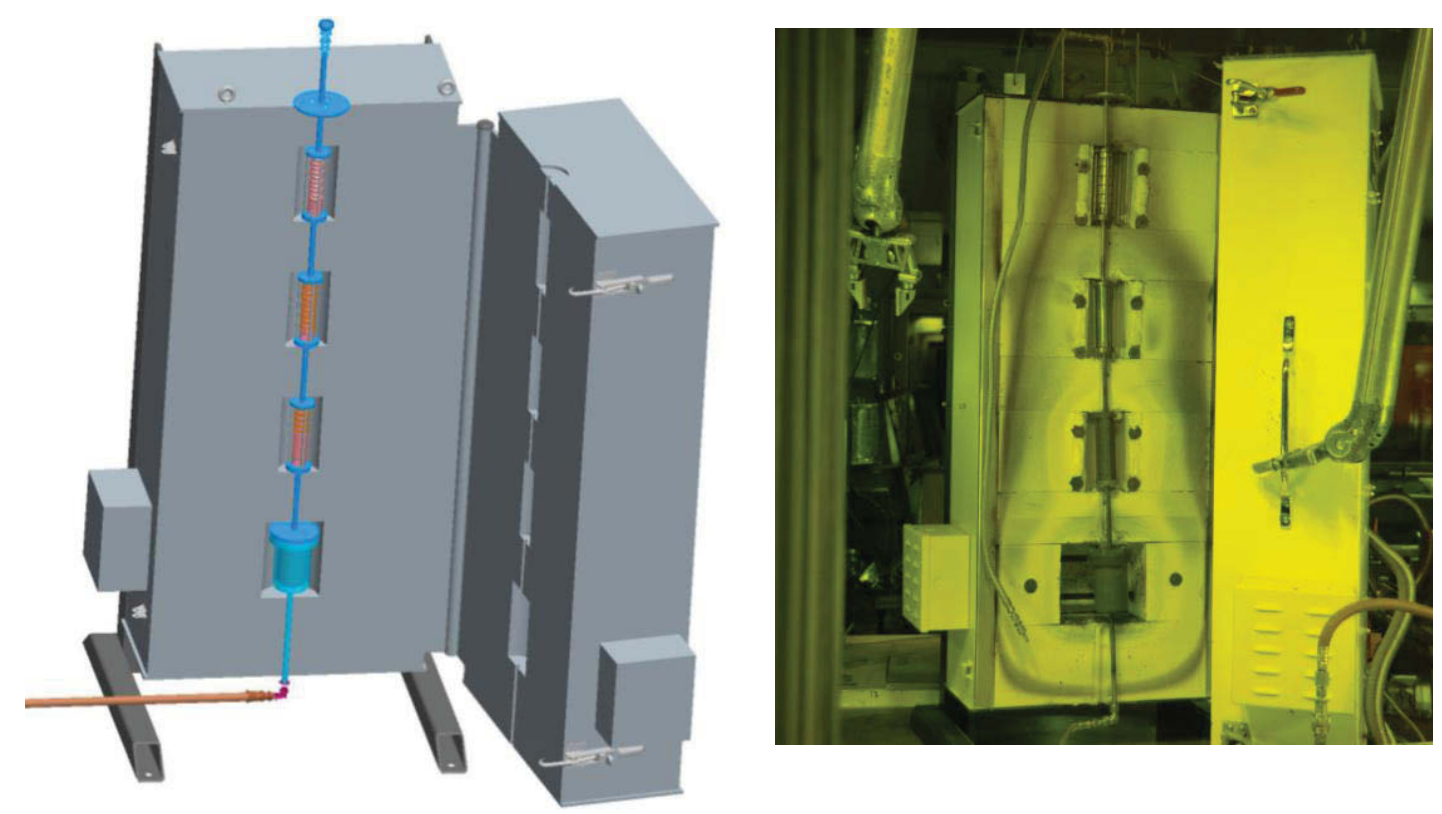

Fig. 9. a) DEOX schematic showing main heat zone (bottom) and upper 3 or trap heat zones. Salt distillation would involve evaporating salt and product in the bottom zone and condensing salt in one of the upper three heat zones. B) DEOX furnace in HFEF.

For dechlorination by salt distillation, the original reaction/filter-bank assembly was modified to include only the lower reaction vessel, to be located in zone 4 of the DEOX furnace, with steel tubing leading to the salt condenser - located in zone three of the furnace as illustrated in the cut away diagram shown in Fig. 10. The tubing exits the top of the salt condenser and extends through zones two and one before exiting the top of the furnace and connecting to the vacuum system. The reaction vessel is constructed of Inconel steel and the condenser, and condenser crucible are constructed of 316 stainles steel. Prior to waste form production, the salt/fission product precipitate is placed into an alumina crucible in the lower reaction chamber and sealed. The assembly is then placed in the furnace and a vacuum $(\sim 70 \mathrm{~Pa})$ is applied to the exit tube from the condenser. The condenser zone (zone 2 of the furnace) is first heated to $500^{\circ} \mathrm{C}$, while the upper two zones are maintained at 300 and $200^{\circ} \mathrm{C}$, respectively, to maintain the salt in the liquid phase and prevent clogging of the system by salt freezing. After the upper zones have reached temperature and with an appropreate vacuum applied, the lower zone is heated to $1100^{\circ} \mathrm{C}$. At this temperature and pressure, the chloride components of the salt/precipitate mixture become volatile and migrate to the condenser region due to a partial pressure gradient. At the condenser, the vapor condenses on the cooler condenser cap and drips into the steel crucible. At these conditions, $100 \mathrm{~g}$ of salt will take less than one hour to distill. Also shown in Fig. 10 is the distillation assembly undergoing "out-of-cell" testing. After distillation, the remaining precipitate product in the reaction chamber crucible and the salt distillate can be recovered for subsequent waste form processing. 

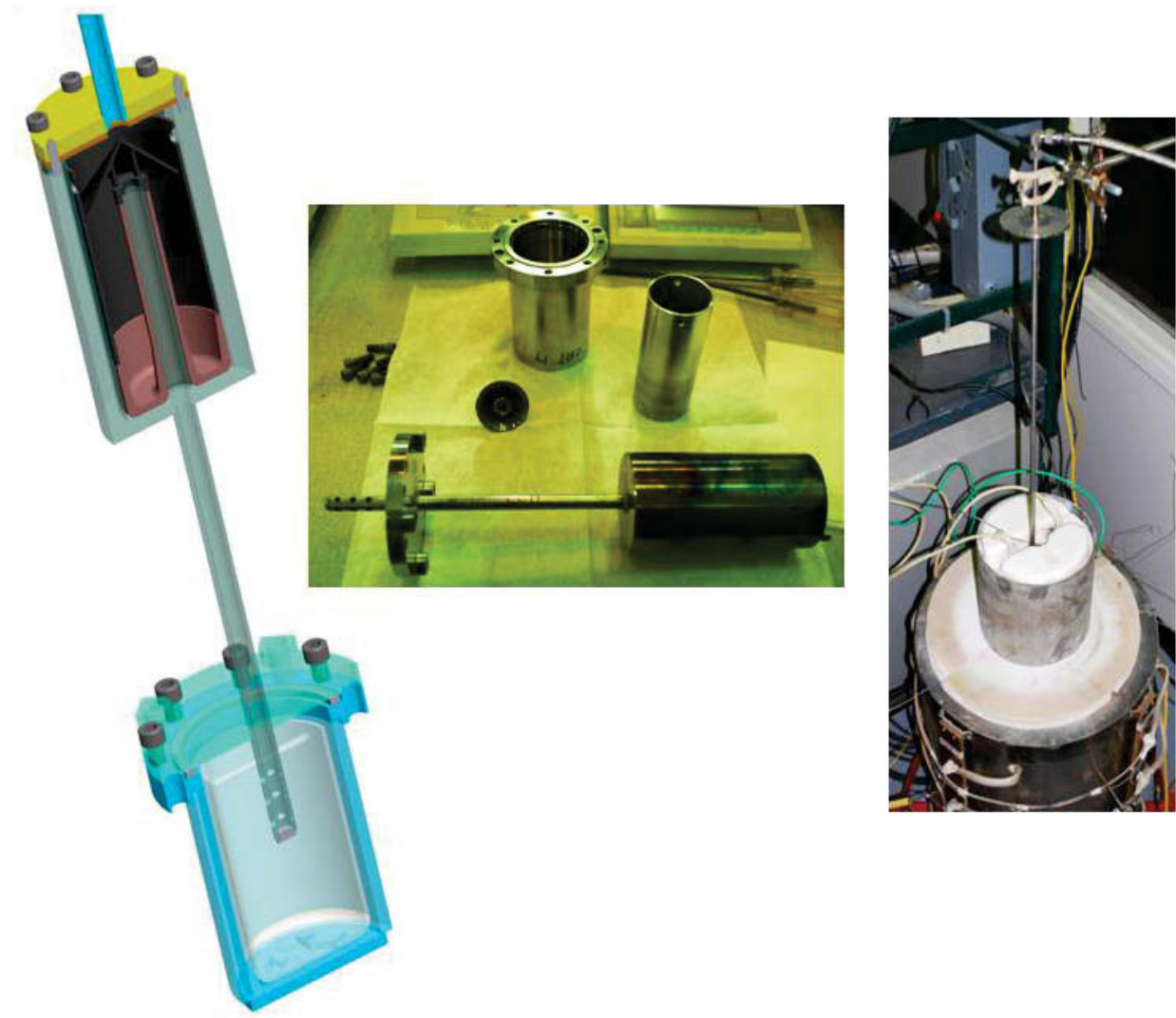

Fig. 10. Salt Distillation assembly (left-hand diagram) mondified for use in the DEOX furnace. Out-of-cell testing is shown in the middle and right-hand images.

The second dechlorination method involves reacting the salt/precipitation product with the SAP reactant in the presence of $\mathrm{O}_{2}$ at elevated temperatures. This process is also performed using a modified reaction assembly in the DEOX furnace. This assembly utilizes the same Inconel reaction vessel and crucible as the distillation assembly, but without the condenser. Also, a gas exhaust exits the bottom of the reaction assembly shown in Fig. 11. Dechlorination proceeds by mixing the salt/precipitate mixture with the SAP reagent and sealing in the reaction vessel assembly, and the assembly is inserted into the DEOX furnace. $\quad \mathrm{An} \mathrm{O}_{2}$ flow of 28 $\mathrm{L} / \mathrm{hr}$ is initiated from the top of the assembly, over the reaction mixture, and exhausted through the bottom of the assembly and furnace. Dechlorination proceeds at $750^{\circ} \mathrm{C}$ in zone 4 for 24 hours. After dechlorination the product is recovered and bonded with glass binder forming the final waste product. Glass bonding of the $\mathrm{SAP} /$ salt product, in addition to CWF production occurs at elevated temperatures using the DEOX furnace under an argon atmosphere. For these reactions, standard alumina or graphite crucibles are used supported in a crucible holder as shown in Fig. 11. For these operations, the crucible and holder is placed in zone 4 of the DEOX furnace to produce the final waste form products. 

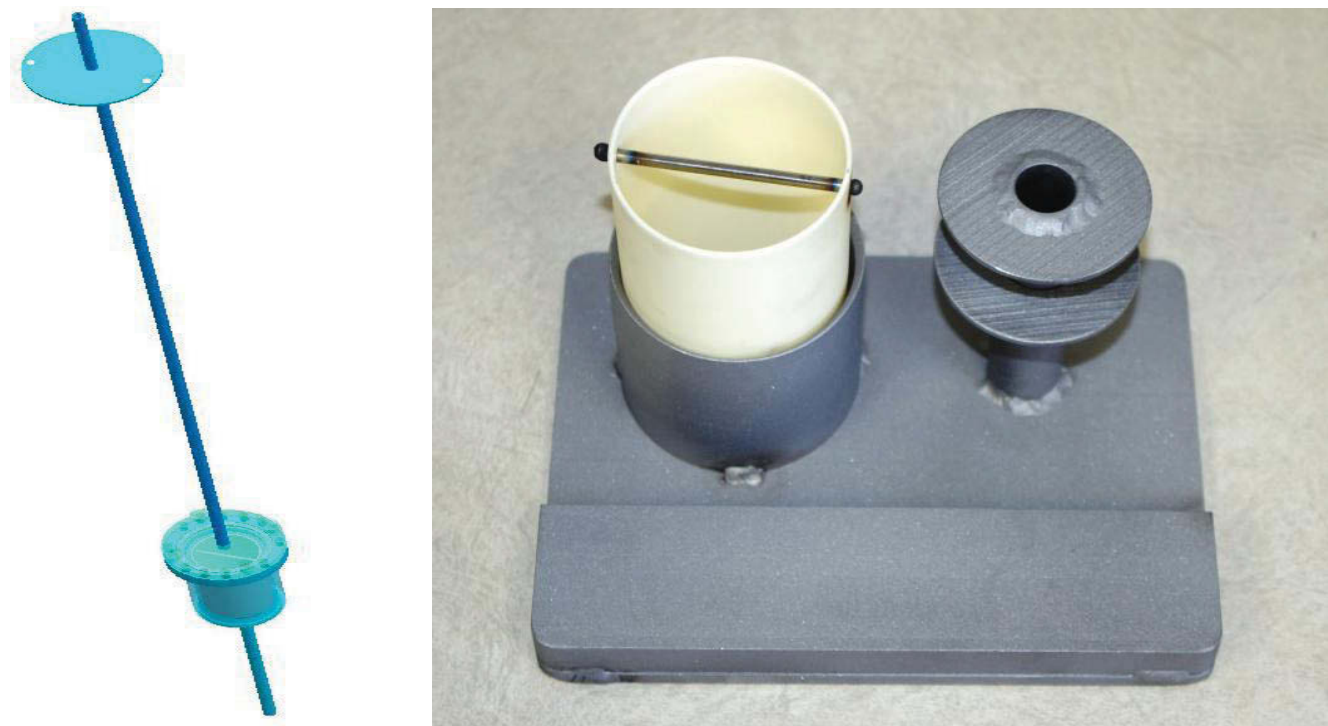

Fig. 11. Dechlorination reaction vessel assembly (left-hand image) with oxygen feed (top) and exhaust (bottom). Standard crucible handling assembly (right-hand photograph) shown for reactions in the DEOX furnace at elevated temperatures under inert (argon) atmosphere.

\section{Advanced Waste Form Production}

Demonstration of the production of three advanced waste form materials during this I-NERI project will be produced in HFEF from ER salt containing actinide and surrogate fission product chlorides. The first advanced CWF product was produced in HFEF during the FY10 time period. The SAP and ZIT waste forms will be produced early in the FY11. A description of the development of the advanced CWF is given blow. The development of the SAP and ZIT waste forms is described in detail in Attachment B of this year-end report (KAERI Activities for 2010). Also provided in this section is the detailed description of each waste form fabrication method performed in the DEOX furnace in HFEF. The overall processing scheme for advanced waste form production is shown in Fig. 12.

\section{Advanced CWF}

The CWF produced by the treatment of EBR-II spent fuel will have a low loading of fission products on the order 2 to 4 weight $\%$. It is possible to produce highloaded CWF with fission product loading on the order of 10 weight $\%$, however, to achieve this level of fission product loading, the fission products must first be concentrated then loaded into the zeolite matrix. A number of proposals to produce high-loaded zeolite have been suggested and in the joint KAERI/INL fission product separation I-NERI, the method selected was immersion of zeolite into a molten salt bath and allowing the fission product cations to undergo equilibrium with the zeolite matrix. For the I-NERI investigations this was accomplished either by placing the zeolite pellets into a steel basket that allowed the molten salt flow through the basket and contact the zeolite; or using an inorganic binder, produce a porous monolithic zeolite. Another method to produce the high-loaded CWF is to load the condensate salt produced by salt distillation of the salt/precipitate mixture, or direct loading of the salt/precipitated mixture into zeolite and then proceed with CWF fabrication. Both advanced CWF fabrication methods were demonstrated for the I-NERI waste form project. 


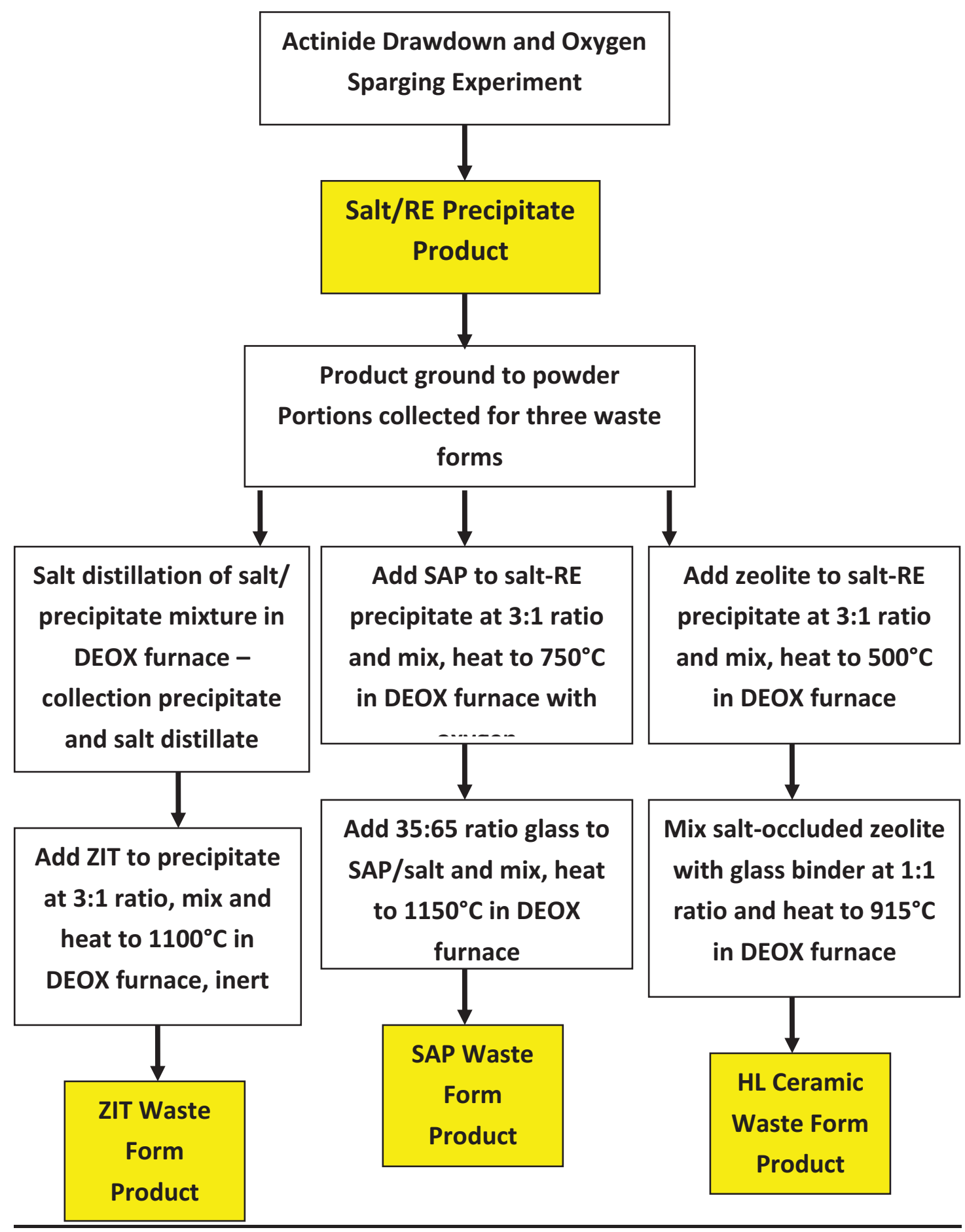

Fig. 12. General processing scheme for advanced waste form production.

Development of the high-loaded CWF was first investigated by using surrogate (none radioactive) fission product loaded ER salt. The first step was to submerge $2 \mathrm{~g}$ of spherical zeolite $(500 \mu \mathrm{m})$, contained in a steel basket, into a molten ER salt stimulant loaded with 8 weight percent (wt $\%$ ) surrogate fission product chlorides. The zeolite was allowed to ion exchange with the molten salt simulate until equilibrium had been obtained. The basket was then removed from the salt bath and the zeolite spheres with residual salt collected. The salt-coated zeolite was then ground to a powder $(\sim 125 \mu \mathrm{m})$ and dry mixed with an equal quantity of dry, non-salt contacted zeolite powder $(125 \mu \mathrm{m})$. This mixture was the heated at $500^{\circ} \mathrm{C}$ for 3 
hours to absorb excess salt. A borosilicate glass binder was then added to the mixture at 25 weight percent and dry mixed a second time. This material was then poured into a $100 \mathrm{cc}$ steel crucible and placed in a furnace at $925^{\circ} \mathrm{C}$ for 3 hours. During the pressureless consolidation of the zeolite and glass, the zeolite converts to sodalite and the liquid glass binds the now converted sodalite particles. The sodalite unit-cell cage structure is smaller that zeolite and cannot incorporate as much $\mathrm{Cl}^{-}$ion. Thus excess $\mathrm{Cl}^{-}$combines with available cations, primarily $\mathrm{Na}^{+}$to form halite inclusions in the glass region of the waste form. The CWF produced from the salt contacted zeolite is shown in Fig. 13. X-ray diffraction (XRD) analysis was performed on the surrogate, high-loaded waste form and is shown in Fig. 14. The XRD analysis shows the sodalite phase shifted to low d-spacings due to ion-exchange with Li and other cations that result in a lattice contraction of the sodalite crystal structure.

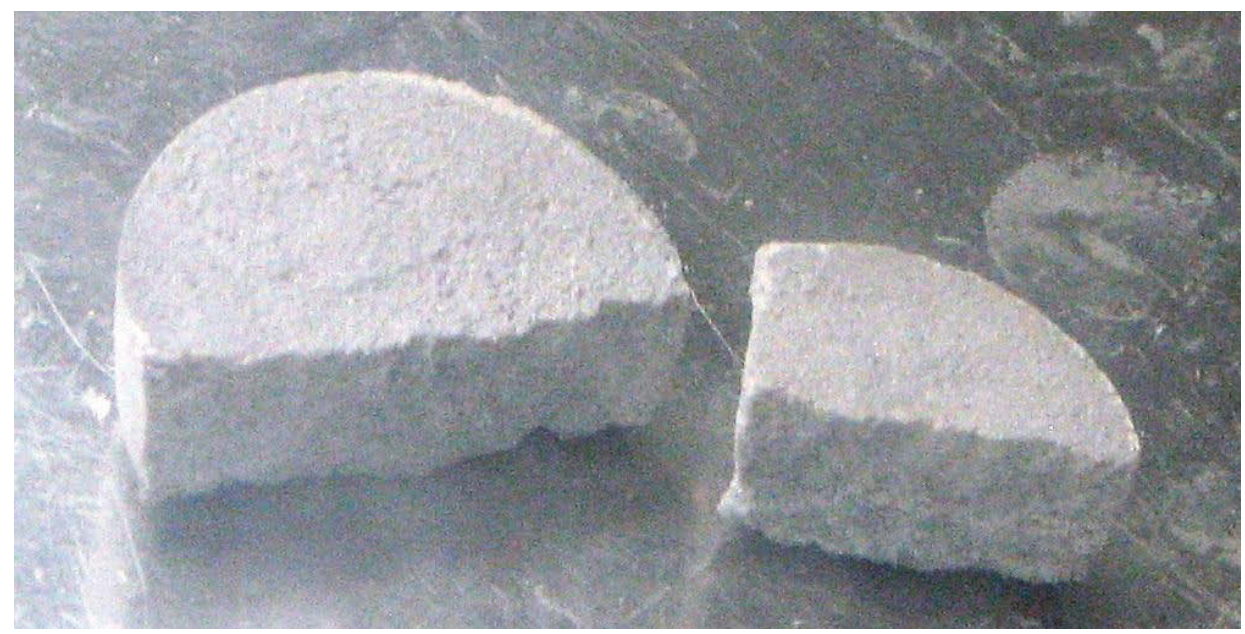

Fig. 13. CWF produced from surrogate high-loaded, salt contacted zeolite. The diameter of the CWF body is $5 \mathrm{~cm}$.

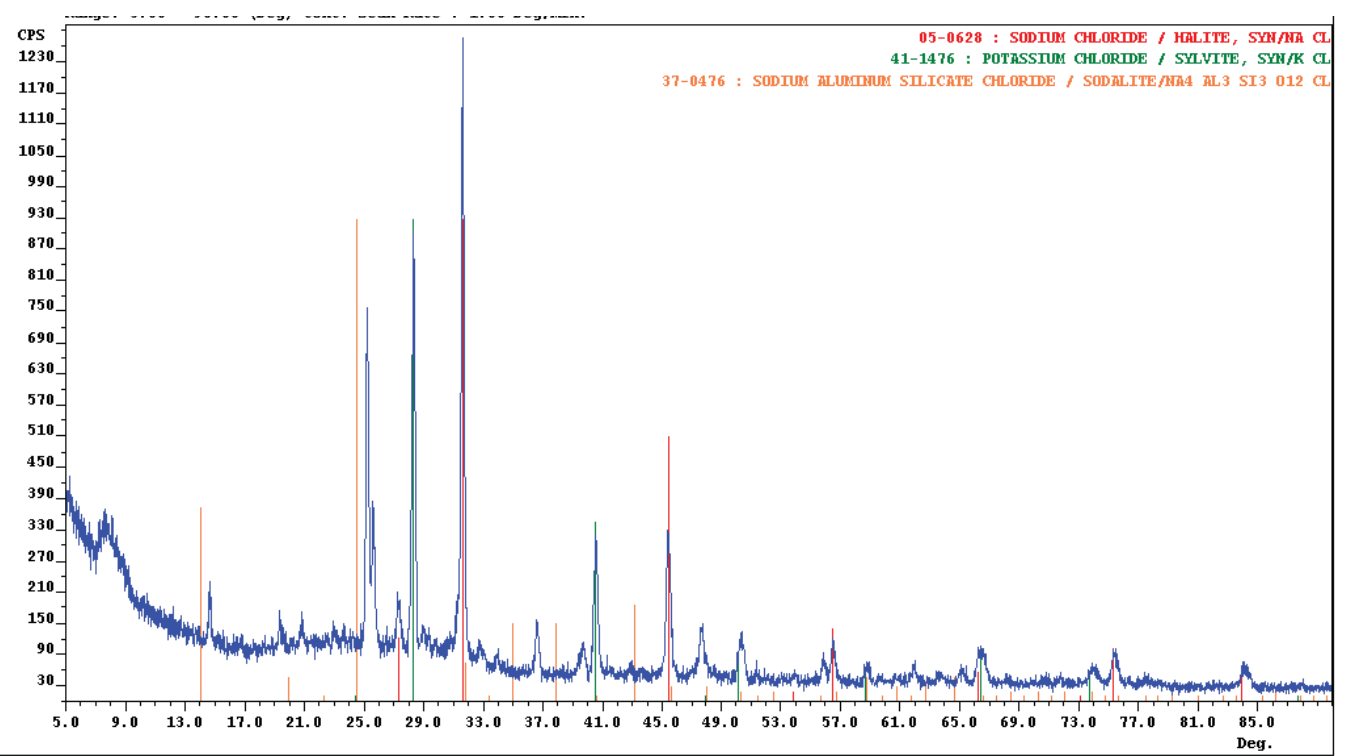

Fig. 14. XRD pattern of surrogate, high-loaded CWF. Major phases identified are sodalite, shifted to low-d spacings and the $\mathrm{NaCl}$ and $\mathrm{KCl}$ salt phases.

The first salt/zeolite demonstration test was performed during the FY09 time period utilizing the HFDA, and involved the zeolite contacting of high fission product loaded ER salt fission products. The electrolyte used was a composite material that 
consisted of 758 grams of salt condensate retrieved from a cathode processor (CP). This composite salt contained sodium, actinides, and fission products from processing EBR-II driver fuel. The non-radioactive rare-earth chlorides: $\mathrm{NdCl}_{3}, \mathrm{CeCl}_{3}, \mathrm{LaCl}_{3}$, $\mathrm{PrCl}_{3}, \mathrm{SmCl}_{3}$, and $\mathrm{YCl}_{3}$, were purposely added to the salt to produce the simulated, high fission product loaded material. The composition of the initial, high-loaded electrorefiner salt was:

- LiCl-KCl: $88.8 \mathrm{wt} \%$

- Alkali elements (Na, Rb, Cs): $1.6 \mathrm{wt} \%$

- Alkaline earth elements (Sr, Ba): 0.8 wt \%

- Lanthanides (La, Ce, Pr, Nd, Sm) and Y: $5.5 \mathrm{wt} \%$

- Actinides (U, Np, Pu Am): 3.3 wt\%

The salt/zeolite contacting portion of the demonstration involved the addition of $8.8 \mathrm{~g}$ of dried zeolite to the zeolite basket and submerging the basket into the HFDA salt bath. The temperature of the salt bath was $500^{\circ} \mathrm{C}$ and the zeolite basket remained in the salt bath for 24 hours while being rotated. After the 24 hour contacting period, the basket assembly was removed from the bath and allowed to cool. The bottom end of the basket was cut off and the zeolite with adhering salt crushed out of the basket. The collected salt contacted zeolite (Fig. 15) was stored for subsequent CWF fabrication.

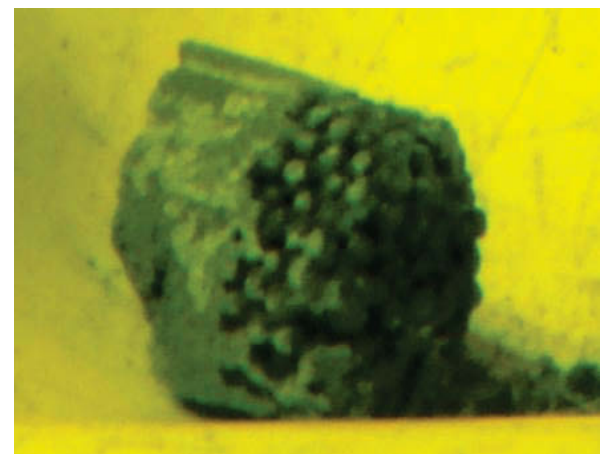

Fig. 15. HFDA salt contacted zeolite. This material will be fabricated into a highloaded CWF in the third year of this I-NERI project.

The second salt/zeolite contacting method to produce the advanced CWF was accomplished during the current year in HFEF. This involved contacting zeolite with high fission product salt containing precipitated lanthanides from the second collection pan produced in the HFDA oxygen sparging experiment. With this method, $10.1 \mathrm{~g}$ of ground salt/precipitate collected from the precipitated collection pan (Fig. 6) was dry mixed with $33 \mathrm{~g}$ of ground, dry zeolite. This mixture was then placed in an alumina crucible (Fig 16.) and inserted into the DEOX furnace. Salt occlusion into the zeolite was performed at $500^{\circ} \mathrm{C}$ for 4 hours under an argon atmosphere. After cool down, this material was mixed with an equal weight of the standard CWF glass binder (boro-silicate gas frit) in powder form. This mixture was then placed back in the alumina crucible, and processed at $925^{\circ} \mathrm{C}$ for 4 hours. The final advanced CWF product is shown in Fig. 17. This material will undergo subsequent characterization and testing in FY11. 


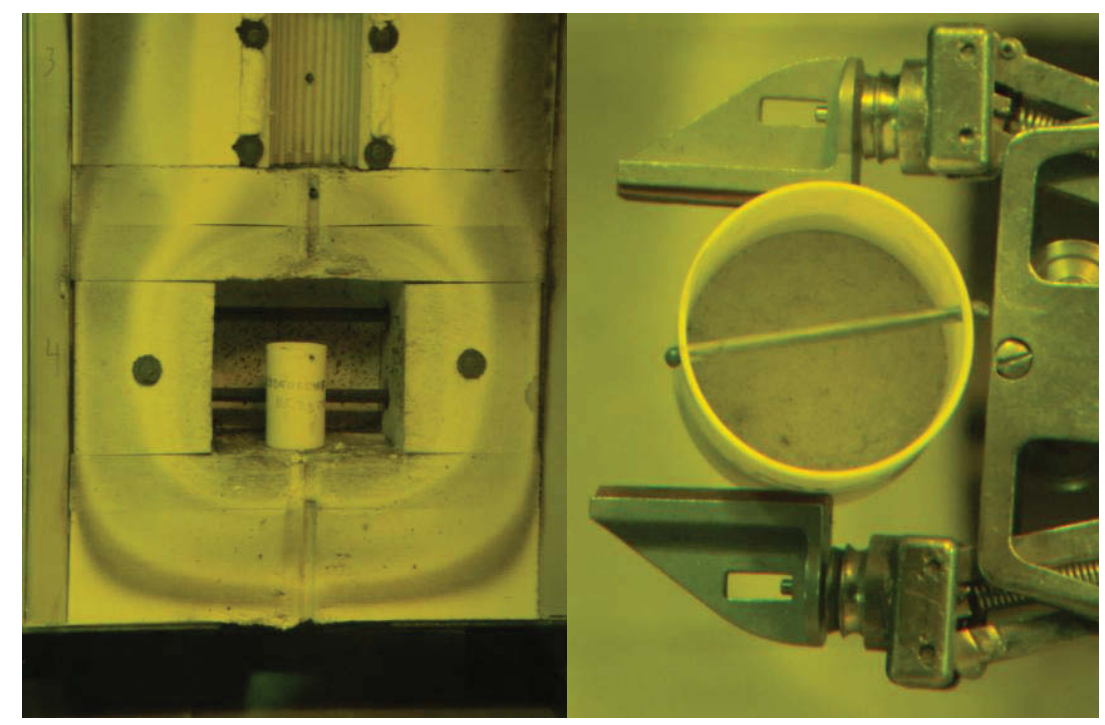

Fig. 16. Alumia crucible in DEOX furnace, zone 4 (left-hand image) loaded with salt/precipitate and zeolite prior to salt occlusion. Loaded crucible (right-hand image) with salt-occluded zeolite.

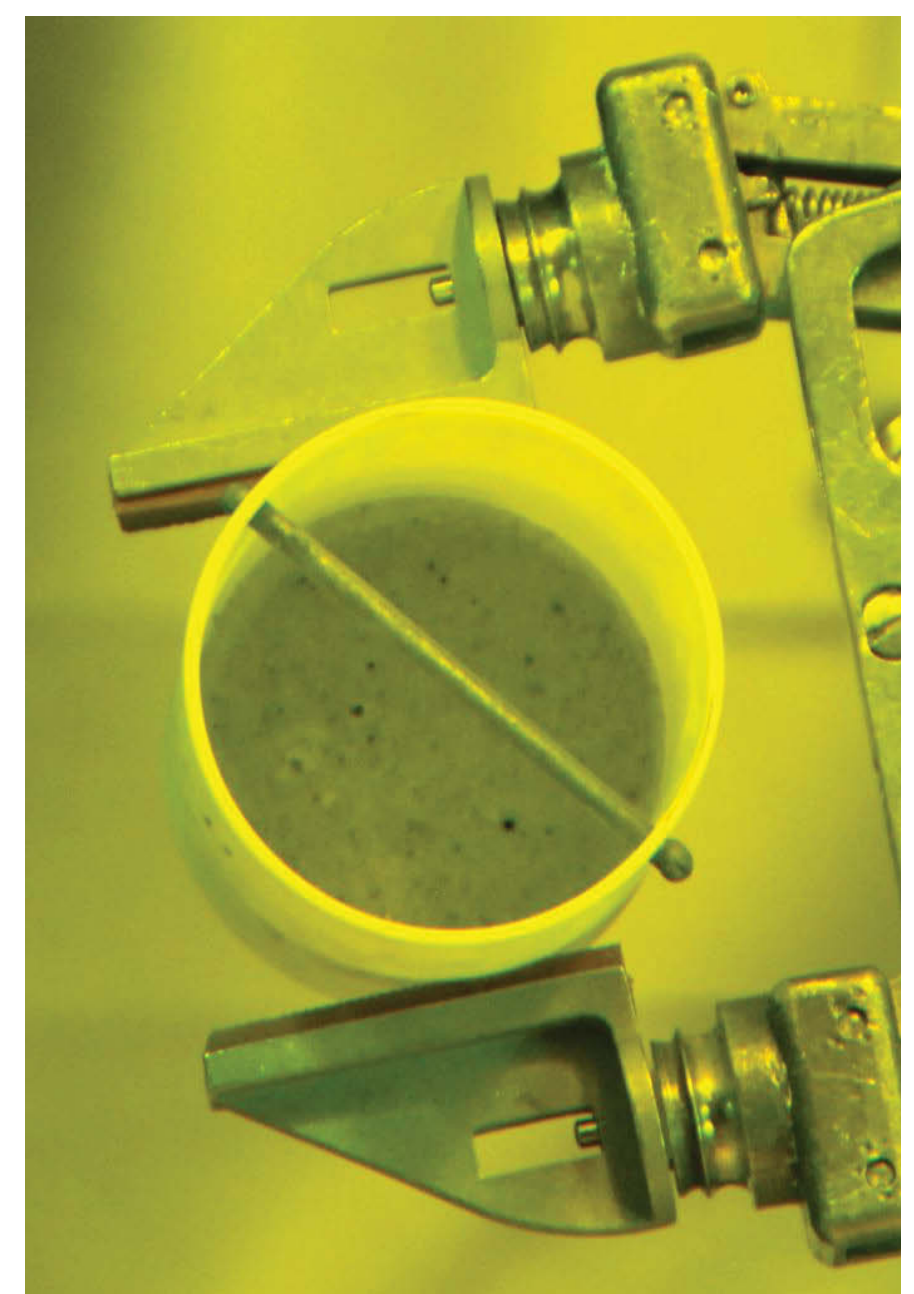

Fig. 17. High-loaded cermaic waste form produced in HFEF. The high fission product (with rare-earth precipitates) salt was loaded to $20 \mathrm{wt} \%$ in the zeolite. The final product is 50:50 salt-occluded zeolite/glass binder. Characterization and testing of the waste form will be performed in the $3^{\text {rd }}$ year of the I-NERI project. 


\section{Advanced Waste Form Fabrication Methods}

The following section describes each of the advanced waste form production methods to be performed in HFEF as part of the I-NERI project.

\section{Advanced CWF}

- Mix 1 part salt/precipitate powder with 4 parts zeolite in reaction crucible

- Place crucible in reaction chamber and seal

- Place reaction chamber in zone 4 of DEOX furnace

- Heat zone 4 of DEOX furnace to $500^{\circ} \mathrm{C}$, heat for 4 hours.

- After furnace cool down, remove crucible and mix glass frit to salt-occluded zeolite in crucible (50:50 ratio)

- Place crucible into steel holder and insert into zone 4 of DEOX furnace

- Heat zone 4 of DEOX furnace to $925^{\circ} \mathrm{C}$, heat for 4 hours under $\mathrm{Ar}$ atmosphere

- After furnace cool down, recover waste form body from crucible and store for subsequent characterization.

2. SAP Waste Form

- Mix 1 part salt/precipitate powder with 3 parts SAP reagent in product crucible

- Place crucible in SAP reaction assembly and seal

- Place reaction chamber in zone 4 of DEOX furnace, connect oxygen line

- Initiate oxygen flow into reaction chamber at $1 \mathrm{scf} / \mathrm{hr}$

- Heat zone 4 of DEOX furnace to $750^{\circ} \mathrm{C}$, heat for 24 hours.

- After 24 hours, turn off oxygen flow and allow furnace to cool

- Remove reaction chamber from DEOX furnace and disassemble

- Collect salt/SAP product from crucible and place into waste form crucible

- Mix glass frit to salt/SAP product in crucible (35:65 ratio)

- Place crucible into steel holder and insert into zone 4 of DEOX furnace

- Heat zone 4 of DEOX furnace to $1150^{\circ} \mathrm{C}$, heat for 8 hours under Ar atmosphere

- After furnace cool down, recover waste form body from crucible and store for subsequent characterization.

3. ZIT Waste Form

- Place salt/precipitate powder into product crucible of salt distillation apparatus - seal salt/precipitate chamber of distillation apparatus

- Place salt distillation apparatus into DEOX furnace, connect vacuum line

- Apply vacuum to salt distillation apparatus until a pressure of at least 1 torr is obtained.

- Heat condenser of distillation apparatus to $500^{\circ} \mathrm{C}$ (zone 3 of furnace), then heat zone 4 of furnace (salt chamber) to $1100^{\circ} \mathrm{C}$, heat for 3 hours while under vacuum

- Allow furnace to cool and disassemble salt distillation apparatus

- Collect salt distillate from condenser and fission product precipitate from bottom chamber of salt distillation apparatus

- Collect fission product precipitate and transfer to waste form crucible 
- Mix 1 part precipitate with 3 parts ZIT reagent in crucible

- Place crucible into steel holder and insert into zone 4 of DEOX furnace

- Heat zone 4 of DEOX furnace to $1100^{\circ} \mathrm{C}$, heat for 8 hours under Ar atmosphere.

- After furnace cool down, recover waste form body from crucible and store for subsequent characterization.

\section{Waste Form Characterization and Testing in HFEF}

Waste form characterization and testing has occurred in HFEF for the last decade. These efforts were performed during the EBR-II Sent Fuel Demonstration Program where the ceramic waste form produced with electrorefiner salt underwent characterization and testing. CWF characterization and testing involved sampling the product in HFEF and then preparing test samples for analysis involved the following:

- Sample preparation: HFEF

- Product consistency testing: HFEF

- Density determination by He pycnometry: HFEF

- Microstructure by electron microscopy: Electron Microscopy Laboratory

- Phase composition by x-ray diffraction: Analytical Laboratory

This will be the same characterization and test suite to be performed on the three advanced waste forms produced in HFEF in FY11.

\section{SUMMARY}

The following summarizes the $2^{\text {nd }}$ year efforts at the INL for I-NERI project tasks A3, A4, and B2.

\section{Task A3 - Setup of Experimental Equipment for Hot-Test (INL)}

Task A3 was completed in FY10 with the testing and implementation of waste form fabrication in the main-cell of HFEF. Equipment fabricated, testing and moved in-cell included the salt distillation assembly, dechlorination assembly, and standard reaction crucible assemblies. In-cell equipment utilized for waste form fabrication included the HFDA (repeat oxygen sparging experiment) and the DEOX furnace.

\section{Task A4 - Screening Experiments for Various Host Matrices (KAERI/INL)}

Task A4 was completed in FY10 with the selection of three candidate advanced waste forms for fabrication in HFEF. The three waste forms selected are the silicaalumina-phosphate/glass (SAP) waste form, the zinc oxide/titania (ZIT) waste form, and the high-loaded ceramic waste form (HL-CWF). The HL-CWF was also fabricated during September, 2010, in HFEF. The two other candidate waste forms will be fabricated early in 2011 in HFEF.

\section{Task B2 - Waste Form Testing with TRU-Loaded Materials (INL)}

Task B2 was initiated in FY10 and will continue into the third year (FY11) of this I-NERI project. Elements of this task completed during 2010 include a repeat of the oxygen sparging method to precipitate rare-earth fission products from ER salt. Prior to oxygen sparging, a U/TRU drawdown process was performed in the molten salt to reduce the actinide concentration in the salt. A salt/rare-earth precipitate 
product was then recovered from the HFDA molten salt bath and this material is the feed for subsequent candidate waste form production. The first of these waste forms, the HL-CWF, was then fabricated in HFEF. Continuing into the $3^{\text {rd }}$ year activities will be the fabrication of the two other candidate waste forms and the characterization and testing of these waste forms. Preparation for waste form characterization and testing will be performed in the newly renovated sample preparation area in the maincell of HFEF. 